\title{
EVALUATION OF THE WOUND HEALING ACTIVITY OF CAESALPINIA BONDUCELLA AND CYCLEA PELTATA EXTRACTS IN EXPERIMENTALLY INDUCED DIABETIC RATS
}

\author{
JAGADEEP CHANDRA S. ${ }^{1}$, MAHADEVA MURTHY S. ${ }^{2 *}$, RANJANA RAMESH ${ }^{3}$ \\ ${ }^{1}$ Department of Studies in Microbiology, University of Mysore, Manasagangotri, Mysuru 570006, India, ${ }^{2 *}$ Department of Microbiology, \\ Yuvaraja's College, University of Mysore, Mysuru 570005, India, ${ }^{3}$ Skanda LifeScience Ltd., Bangalore 560091, India \\ Email: smmurthy2025@gmail.com \\ Received: 08 May 2017 Revised and Accepted: 31 Aug 2017
}

\begin{abstract}
Objective: The present study was conducted to verify the effect of Caesalpinia bonducella and Cyclea peltata extracts on experimentally induced excision wounds in diabetic rats.
\end{abstract}

Methods: Methanolic and ethyl acetate extract of test sample in PEG base was applied and observed for wound healing effect for a period of $15 \mathrm{~d}$.

Results: The data demonstrated statistically significant wound contraction up to $98 \%$ in the treated sample as compared to $90 \%$ in diabetic control group. The results correlated $(r \geq 0.95)$ with fasting blood glucose level, indicating the deleterious effect of hyperglycemia in wound healing. Histopathological studies indicated moderate granulation with marked epithelial enclose and moderate hyperplasia in groups treated with high dose (100 mg/kg BW) of methanolic extract of aerial part of Cyclea peltata and root of Caesalpinia bonducella.

Conclusion: From the study, it can be hypothesized that tested plant extracts favours wound healing in diabetic animals and paves the way for the more detailed study of the phytochemical constituent for therapeutic applications. The present investigation adds to the existing knowledge in the field of therapeutic medicine and may even become the base for the development of herbal based gel formulations or ointments for treating wounds in diabetic patients and thereby continuous usage of synthetic drugs, its associated side effects could be avoided.

Keywords: Wound healing, Diabetic rats, Blood glucose, Histopathology and Excision wounds

(C) 2017 The Authors. Published by Innovare Academic Sciences Pvt Ltd. This is an open-access article under the CC BY license (http://creativecommons.org/licenses/by/4.0/) DOI: http://dx.doi.org/10.22159/ijpps.2017v9i10.19788

\section{INTRODUCTION}

Wounds are unavoidable events of life, which arise due to physical, chemical injury or microbial infections. The wound may be defined as a loss or breaking of cellular and anatomic or functional continuity of living tissues [1]. The wound healing process is a complex series of events that begins at the moment of injury and can continue for months to years. The basic principle of optimal wound healing is to minimize tissue damage and provide adequate tissue perfusion and oxygenation, proper nutrition and moist wound healing environment to restore the anatomical continuity and function of the affected part [2]. Healing of wounds requires the collaborative efforts of many different tissues and cell lineages [3]. The process involves different phases such as coagulation, epithelization, granulation, collagenation and tissue remodelling.

In the present fast life, a drastic increase in chronic disease conditions mainly diabetes has been observed which is one of the major contributors to persistent wound healing problem [4]. Diabetic wounds are slow, non-healing wounds that can persist for weeks despite adequate and appropriate care and can lead to irreversible septic gangrene and even amputations [5]. Vascular, neuropathic, immune function and biochemical abnormalities contribute to the altered tissue repair in diabetic patients. Currently, very few FDA approved therapies such as growth factor and cell therapies are available [6]. Some of the commonly available drugs used in the healing of wounds are NSAIDs ibuprofen (non-steroidal anti-inflammatory drug), colchicine, corticosteroids, antiplatelet (aspirin), anticoagulants (heparin), warfarin and vasoconstrictors e. g., nicotine, cocaine and adrenaline [7]. Despite the available treatment along with proper glucose control and meticulous wound care, the prognosis for wound healing is poor $[8,9]$.

The presence of various life-sustaining constituents in plants has urged scientists to focus on plants especially for their immense potential in healing wounds. A large number of plants are used by folklore traditions in India for treatment of cuts, wounds, ulcers, inflammation and burns [10, 11]. Plant extracts are popularized because of the absence of unwanted side effects and effectiveness as crude preparations. Plant-based therapy not only accelerates healing process but also maintains aesthetics [12].

Many scientists around the world have recently reported on wound healing activity of some medicinal plants. To state a few, ethanolic extract of Heliotropium indicum [13], latex of Calotropis gigantean [1], methanolic extract of Hypericum patulum Thumb. Leaves [14] have been demonstrated to have significant wound healing activity.

Caesalpinia bonducella and Cyclea peltata are potent medicinal herbs and are well known in ayurveda and folk medicine systems [15]. During the field survey and documentation of Ethno-medico-botanical knowledge, it was found that local folk medicine practitioners residing in Nagapurahaadi and Haemmegaehaadi tribal settlements of Hunsurtaluk, Mysuru district, Karnataka, India, traditionally use these plants as one of the ingredients in their herbal formulations used in the treatment of wounds and skin infections.

Caesalpinia bonducella (Linn.) Flem. belongs to family caesalpiniaceae and its English name is fevernut or bonduc nut. In Ayurveda, it is well known as Latakaranja $[16,17]$. It is large straggling prickly shrub with branches and petioles armed with hard yellow prickles. Leaves are an alternate, large, $30-50 \mathrm{~cm}$ in length, bipinnate, with foliaceous stipules [18-20]. The inflorescence is supra-axillary panicled raceme at top of branches, in dense, long-peduncled, yellow coloured flowers. Fruits are pods, oblong or globular in shape, $5-8 \mathrm{~cm}$ in length, bivalve, hard and with spines. Seeds are lead-coloured, globose, large, hard and with smooth shiny surface [19-21].

Caesalpinia bonducella is found distributed throughout India and tropical countries of the world [18]. In India, it is found growing along coastal areas especially in West Bengal and the whole of Southern India [22]. In Karnataka, it is commonly distributed in 
Banglore, Bidar, Chikmagalur, Chitradurga, Coorg, Hassan, Mysuru, North kanara, raichur and shimoga districts [21].

In Indian traditional system of medicine seeds, leaves, barks and roots of Caesalpinia bonducella are well known for their usage in the treatment of various ailments $[17,23]$. Tender leaves are used in the treatment of liver complaints [24]. Leaves and bark are used as febrifuge, emmenagogue and anthelmintic [25]. Seeds are used by folk medicinal practitioners in the treatment of piles, vomiting, leprosy, a disorder of the blood, spleenic disorder and cut wounds $[21,26]$.

Cyclea peltata (Lam.) Hook. f. and Thomson is a member of the family Menispermaceae, and its English name is Pata root [27]. In ayurveda, it is well known as rajapatha [28], and is referred in most of the ayurvedic texts like Charaka Samhita, sushrutasamhita and ashtangahridya. It is a slender much-branched twining shrub, usually climbing up on tall trees, has tuberous roots and drupaceous reniform fruits. Its leaves are simple, alternate, petioles long, lamina peltate and 2-5 cm long. Flowers are small, greenish yellow in colour, situated in auxiliary panicles. It is a pungent smelling plant, having a bitter taste. It has been reported for having antipyretic and astringent activities [28-32]. The tuberous root is cylindrical, irregularly curved, with grayish brown surface and white starchy cortex. On drying, the surface becomes dark brown and wrinkled and the cortex yellowish grey [33].

The global distribution of this species is recorded from India to Malaysia, including Srilanka and Andaman and Nicobar islands. Within India's mainland, it grows in areas having elevation up to $800-900 \mathrm{~m}$ [31]. Its habitat is mainly recorded in the Western Ghats of Karnataka, Maharashtra, Kerala and Tamil nadu and in other moist deciduous forests of Peninsular India [34]. In Karnataka, it is distributed in Bellary, Chikmagalur, Coorg, Hassan, Mysuru, North kanara, Shimoga, South kanara districts [21].

The plant Cyclea peltata is widely used in folk medicine for the treatment of a cough, fever, kidney disorder, urinary disorder and snake poisoning [32]. The Kani tribes in Aarukani Hills of Tamil Nadu use tuber and leaves of Cyclea peltata to treat Chickenpox, diarrhea, wounds and scabies [35]. The leaves of $C$. peltata were being used by folk medicinal practitioners as coolant, antidandruff, antipyretic and diuretic [36, 37]. In parts of costal Karnataka, leaves are being traditionally used for the treatment of herpes [38].

The extracts from these plants have been speculated to possess many important medical applications which make them a potential substrate for researchers prospecting for active compounds to provide intervention for the global therapeutics. However, extensive literature review indicated that not much work has been reported on the wound healing activity of these selected plants and hence was selected for the present study. The aerial part of Cyclea peltata as well as roots of Caesalpinia bonducella were extracted with methanol and studied for wound healing effect using excision wound model of Streptozotocin (STZ) induced diabetic Wistar albino rats.

\section{MATERIALS AND METHODS}

\section{Chemicals and reagents}

All chemicals and solvents used were of analytical grade. Streptozotocin and polyethene glycol (PEG) were purchased from Sigma Chemical Co. (USA).

\section{Collection of plant material}

Fresh plant materials of Caesalpinia bonducella (leaf, bark and root) and Cyclea peltata (entire aerial part) were collected from Nagapurahaadi and Haemmegaehaadi tribal settlements of Hunsur taluk, Mysuru district, Karnataka, India. The plants were photographed, taxonomically identified and their herbarium specimens were deposited in the Department of Pharmacognosy, Herbarium Collection Centre, JSS College of Pharmacy, Mysuru, India with specimen number Caesalpinia bonducella-JSSCP/PCOG/HRBM09 and Cyclea peltata JSSCP/PCOG/HRBM-06. The fresh plant materials were washed under running tap water, wiped with a clean dry cloth, shade dried for seven days and ground to a coarse powder and stored in airtight containers separately.

\section{Extraction of plant materials}

Caesalpinia bonducella (leaf, bark and root) and Cyclea peltata (entire aerial part) powder (500 g each) was subjected to Soxhlet extraction using ethyl acetate and methanol, respectively for $8 \mathrm{~h}$ at $50{ }^{\circ} \mathrm{C}$ followed by filtration using double-layered muslin cloth and then through Whatmann No.1 filter paper to get clear filtrate. Solvents were evaporated in a rotary evaporator and dried separately in desiccators to obtain a solvent-free residue and were stored at $4{ }^{\circ} \mathrm{C}$ in airtight brown bottles until further use.

\section{Experimental animals care and ethical approval}

Seven to eight weeks of in-house breed male Wistar albino rats having body weight ranging from 150-160g were selected for the study. The animal study was performed in animal house facility, Live on Biolabs Pvt. Ltd. Tumkur, with due permission from Institutional Animal Ethics Committee (IAEC) (Study no.: LBPL-EF-011/15). The animal care and handling were carried out according to Committee for the Purpose of Control and Supervision of Experiments on Animals (CPCSEA) guidelines. The investigation was carried under the regular supervision of expertise in animal handling and care.

The animals were housed under standard laboratory conditions. The experimental room was air-conditioned with an adequate fresh air supply (Air changes 12-15 per hour). The room temperature was maintained at $22 \pm 3{ }^{\circ} \mathrm{C}$ and the relative humidity at $30-70 \%$, with $12 \mathrm{~h}$ light and $12 \mathrm{~h}$ dark, light cycle. The temperature and relative humidity were recorded once daily. The animals were acclimatized for five days to laboratory conditions and were observed for clinical signs and behaviour daily. Maximum of three animals were housed in a standard polypropylene cage. The animals were fed ad libitum with AMRUT Laboratory Animal Feed manufactured by Pranav Agro Industries Limited, Sangli, throughout the acclimatization period and study period.

\section{Induction of diabetes}

Diabetes was induced by administration of Streptozotocin (STZ). STZ dissolved in citrate buffer $(0.01 \mathrm{M}, \mathrm{pH} 4.5)$ at a dose of $40 \mathrm{mg} / \mathrm{kg} \mathrm{BW}$ was intraperitoneally injected as a single dose on day 1 [39]. Group G1 animals $(n=4)$ were not treated with STZ and it was considered as non-diabetic control. After $48 \mathrm{~h}$ of STZ administration blood was drawn from the tail by vein puncture and the fasting blood glucose were checked by using glucometer (Glucocard vital strip method). The animals showing higher blood glucose $(>230 \mathrm{mg} / \mathrm{dL})$ were selected and equally distributed to the all groups (G2-G11).

\section{Experimental design}

Grouping of animals was done on the last day of acclimatization or $48 \mathrm{~h}$ after Streptozotocin (STZ) administration. The animals were randomly divided into 11 groups $(n=4)$. Groups G1, G2 and G3 were considered as control, diabetic control and positive control respectively. Groups G1and G2 was treated with only Polyethylene glycol (PEG) gel base without any drug or plant extract, whereas Group 3 (positive control) was treated with $0.50 \mathrm{mg} / \mathrm{kg}$ BW dose of Framycetin ointment.

Group 4: Cycleapeltata aerial part-Methanol extract-(AM)-50 mg/kg BW

Group 5: Cycleapeltata aerial part-Methanol extract-(AM)-100 $\mathrm{mg} / \mathrm{kg} \mathrm{BW}$

Group 6: Caesalpinia bonducella root-Methanol extract-(RM)-50 $\mathrm{mg} / \mathrm{kg} \mathrm{BW}$

Group 7: Caesalpinia bonducella root-Methanol extract-(RM)-100 $\mathrm{mg} / \mathrm{kg} \mathrm{BW}$

Group 8: Caesalpinia bonducella bark-Ethylacetate extract-(BE)-50 $\mathrm{mg} / \mathrm{kg} \mathrm{BW}$

Group 9: Caesalpinia bonducella bark-Ethylacetate extract-(BE)-100 $\mathrm{mg} / \mathrm{kg} \mathrm{BW}$

Group 10: Caesalpinia bonducella leaf-Ethylacetate extract-(LE)-50 $\mathrm{mg} / \mathrm{kg} \mathrm{BW}$

Group 11: Caesalpinia bonducella leaf-Ethylacetate extract-(LE)-100 $\mathrm{mg} / \mathrm{kg} \mathrm{BW}$ 


\section{Formulation}

The plant extracts formulations were prepared by using Polyethylene glycol (PEG) base where the required quantity of test plant extracts was weighed as per the dose and was uniformly suspended in PEG to get the desired concentration. During trial period, adjustment in concentration was made according to increase in body weight (BW) of experimental rats. Framycetin ointment of $0.50 \mathrm{mg} / \mathrm{kg} \mathrm{BW}$ was used in the treatment of positive control group-3. The formulated test sample and Framycetin ointment were applied topically/dermally at wound region as described by Kapoor and Kakkar, [40]. The test sample was daily formulated freshly and topically applied at wound region to experimental animals.

\section{Excision wound model}

The test plant extracts were studied for wound healing effect by excision wound model. The dorsal skin of the Wistar albino rats of groups G1 to G11 was shaved with an electric clipper. Circular pieces $(300 \mathrm{~mm} 2)$ of full-thickness skin were cut off from predetermined areas on the back of the rats under ether anaesthesia [41]. Haemostasis was achieved by blotting the wound with a cotton swab soaked in normal saline and the entire wound was left open. The initial area of the wound was traced on $1 \mathrm{~mm}$ graph paper on the day of wounding and subsequently on alternate days for $15 \mathrm{~d}$ [42].

The wounds in the non-diabetic control G1 group and diabetic control G2 group were topically applied with vehicle alone (PEG) without any test extracts. The Framycetin ointment $(0.50 \mathrm{mg} / \mathrm{kg}$ Bwt) was topically applied at wound area to the positive control G3 group. The test plant extracts formulations were topically applied at wound area of G4 to G11 animal groups as per the above-mentioned study design.

Fasting blood glucose for all the animal groups (G1-G11) were checked by using glucometer (Glucocard vital strip method) subsequently on alternate days for the next $15 \mathrm{~d}$. Individual animal body weights were recorded on the day of receipt and weekly $( \pm 1 \mathrm{~d})$ thereafter during the study period. All animals were observed twice daily for any clinical signs of toxicity, mortality and morbidity.

\section{Measuring wound healing activity}

The progressive changes in wound area were monitored planimetrically by tracing the wound margin on a $1 \mathrm{~mm}$ graph paper on day-1, day-3, day-5, day-10 and day-15. The percentage of wound contraction was measured by using following formula.

$$
\% \text { Wound contraction }=\frac{\text { Healed area }}{\text { Total area }} \times 100
$$

\section{Histopathology}

After the completion of the study period, on day 15, all the animals were humanely sacrificed by exposing them to excess carbon-dioxide in the gas chamber and the animals were subjected to external and internal gross necropsy. The excision wound area was collected and preserved in $10 \%$ Neutral Buffered Formalin (NBF). These tissues were embedded in paraffin wax, sectioned at $5 \mu \mathrm{m}$ and stained with haematoxylin and eosin then subjected to the histopathological evaluation [43].

\section{Statistical analysis}

The raw data obtained were subjected to One-Way ANOVA (Analysis of Variance) with Dunnett's post-test for the data on body weights and clinical chemistry parameters were analyzed by using GraphPad Prism Version 5.01 Software. All analyses and comparisons were evaluated at the $95 \%$ level of confidence $(p<0.05)$. The data generated were compared with the control (non-diabetic) and positive control group.

\section{RESULTS}

Body weight and fasting blood glucose level of experimental animals

Body weight of experimental rats was measured weekly on day-1, day-8 and day-15. There were no statistically significant changes $(p>0.05)$ in the body weight across all the groups during the study period. The summary of fasting blood glucose values of animals are presented in table 1. Streptozotocin induces diabetes through the destruction of beta cells of the pancreas which is evident in the present study by the rise in blood glucose level. After induction, the test group (G2-G11) showed appreciable $(\mathrm{p}<0.05)$ increase in blood glucose level as compared to control (G1). The diabetes was ensured in all the groups (except G1) from day 1 onwards till day 15 of the study period. The fasting blood glucose levels noticed were high on day 1 , day 3 and then showed the trend in the reduction of blood glucose levels from day 5 to day 15 gradually. Comparatively, the rate of reduction was found higher in tested sample group (G3-G11) than in control diabetic group (G2).

\section{Wound healing activity}

The summary of wound measurement $\left(\mathrm{mm}^{2}\right)$, wound healed area measurement $\left(\mathrm{mm}^{2}\right)$ and wound contraction (\%) on day 15 are presented in table 2. Fig. 1 represents the changes in wound size during the experimental period. As expected diabetic condition had a major impact on wound healing process and showed only $90.9 \%$ contraction as compared to control (non-diabetic) with $97.3 \%$ contraction. Positive control group treated with Framycetin showed statistically significant $(\mathrm{p}<0.05)$ percentage of wound contraction $(100 \%)$ with a healed area of $315 \mathrm{~mm}^{2}$. In the diabetic control group, healing of wound was found delayed which may be correlated with elevated blood glucose level.

Table 1: Fasting blood glucose (mg/dl) values of experimental rats

\begin{tabular}{|c|c|c|c|c|c|c|}
\hline Group & Day 1 & Day 3 & Day 5 & Day 7 & Day 10 & Day 15 \\
\hline G1 & $101.5 \pm 8.2$ & $90.5 \pm 17.5$ & $77.8 \pm 11.5$ & $108.5 \pm 12.8$ & $78.3 \pm 6.7$ & $75.3 \pm 9.6$ \\
\hline G2 & $299.5 \pm 37.4$ & $323.5 \pm 40.0$ & $299.8 \pm 36.7$ & $289.5 \pm 57.3$ & $268.0 \pm 39.7$ & $219.5 \pm 24.2$ \\
\hline G3 & $312.8 \pm 14.5$ & $313.3 \pm 16.6$ & $309.3 \pm 36.0$ & $269.8 \pm 32.3$ & $236.8 \pm 42.1$ & $210.0 \pm 19.5$ \\
\hline G4 & $337.3 \pm 61.2$ & $324.5 \pm 28.1$ & $288.0 \pm 27.2$ & $274.3 \pm 34.8$ & $250.0 \pm 26.2$ & $203.8 \pm 24.0$ \\
\hline G5 & $352.0 \pm 46.2$ & $310.5 \pm 36.6$ & $284.3 \pm 43.3$ & $262.0 \pm 22.1$ & $236.5 \pm 48.7$ & $217.5 \pm 42.6$ \\
\hline G6 & $334.3 \pm 56.0$ & $327.3 \pm 37.7$ & $283.5 \pm 52.5$ & $280.8 \pm 23.0$ & $227.8 \pm 45.7$ & $196.0 \pm 34.3$ \\
\hline G7 & $338.8 \pm 41.6$ & $320.5 \pm 10.7$ & $296.5 \pm 10.5$ & $263.8 \pm 20.6$ & $246.5 \pm 41.3$ & $208.8 \pm 17.2$ \\
\hline G8 & $331.0 \pm 57.3$ & $339.5 \pm 42.3$ & $282.3 \pm 56.7$ & $260.3 \pm 57.6$ & $222.0 \pm 47.9$ & $199.3 \pm 14.6$ \\
\hline G9 & $359.3 \pm 37.8$ & $344.3 \pm 49.2$ & $301.0 \pm 54.3$ & $246.5 \pm 57.0$ & $258.8 \pm 63.9$ & $228.0 \pm 37.0$ \\
\hline G10 & $382.5 \pm 31.6$ & $349.8 \pm 91.5$ & $324.5 \pm 91.0$ & $301.8 \pm 90.3$ & $279.0 \pm 66.8$ & $227.0 \pm 35.9$ \\
\hline G11 & $367.8 \pm 45.8$ & $321.0 \pm 58.6$ & $304.5 \pm 27.1$ & $248.8 \pm 18.1$ & $238.0 \pm 22.9$ & $218.8 \pm 22.3$ \\
\hline
\end{tabular}

Values are mean \pm standard deviation $(n=6)$

In experimental rats, treated with high dose $(100 \mathrm{mg} / \mathrm{kg} \mathrm{BW})$ of methanolic extract of aerial part of Cyclea peltata (G5) and the root of Caesalpinia bonducella (G7) showed significantly $(\mathrm{p}<0.05)$ a high percentage of contraction (98\%) as compared to control diabetic rats (G2). The wound contraction and the reduction in wound area can be observed in fig. 1. Mild increase in wound healing contraction (\%) was observed in G4, G6, G11 and marginal at G8, G9 and G10 group. 
Table 2: Wound healing studies. Wound measurement $\left(\mathrm{mm}^{2}\right)$, wound healed area measurement $\left(\mathrm{mm}^{2}\right)$ and wound contraction (\%) on day 15

\begin{tabular}{llllll}
\hline Group & D 3 & D 5 & D 10 & D 15 & $\begin{array}{l}\text { Wound healed area } \\
\text { (D 3-D 15) }\end{array}$ \\
\hline G1 & $320.50 \pm 16.42$ & $300.50 \pm 7.72$ & $62.25 \pm 22.51$ & $8.50 \pm 2.08$ & $312.00 \pm 18.26$ \\
G2 & $314.75 \pm 10.37$ & $294.50 \pm 11.73$ & $125.00 \pm 24.47$ & $28.50 \pm 6.61$ & $286.25 \pm 11.90$ \\
G3 & $315.00 \pm 12.54$ & $297.00 \pm 11.40$ & $65.50 \pm 16.82$ & $0.00 \pm 0.00$ & $315.00 \pm 12.54$ \\
G4 & $314.50 \pm 22.31$ & $292.50 \pm 23.19$ & $77.75 \pm 23.44$ & $17.50 \pm 5.51$ & $297.00 \pm 24.15$ \\
G5 & $321.75 \pm 24.20$ & $293.75 \pm 16.21$ & $67.00 \pm 44.55$ & $6.50 \pm 6.14$ & $315.25 \pm 20.93$ \\
G6 & $320.25 \pm 8.30$ & $320.50 \pm 36.88$ & $86.25 \pm 27.58$ & $15.50 \pm 17.84$ & $304.75 \pm 20.34$ \\
G7 & $324.50 \pm 15.37$ & $310.00 \pm 10.74$ & $81.50 \pm 36.61$ & $3.75 \pm 2.99$ & $320.75 \pm 16.11$ \\
G8 & $329.00 \pm 14.81$ & $305.50 \pm 17.71$ & $77.00 \pm 16.12$ & $27.50 \pm 17.46$ & $301.50 \pm 31.42$ \\
G9 & $313.00 \pm 17.26$ & $293.00 \pm 13.04$ & $66.00 \pm 13.98$ & $22.00 \pm 9.93$ & $291.00 \pm 24.18$ \\
G10 & $326.00 \pm 5.48$ & $308.25 \pm 6.08$ & $64.75 \pm 11.30$ & $25.75 \pm 10.90$ & $300.25 \pm 11.70$ \\
G11 & $328.50 \pm 9.29$ & $307.50 \pm 10.25$ & $68.25 \pm 10.08$ & $17.75 \pm 9.43$ & $310.75 \pm 12.23$ \\
\hline
\end{tabular}

Values are mean \pm standard deviation $(n=6) ; p<0.05^{*} ; \mathrm{p}<0.01^{* *}$

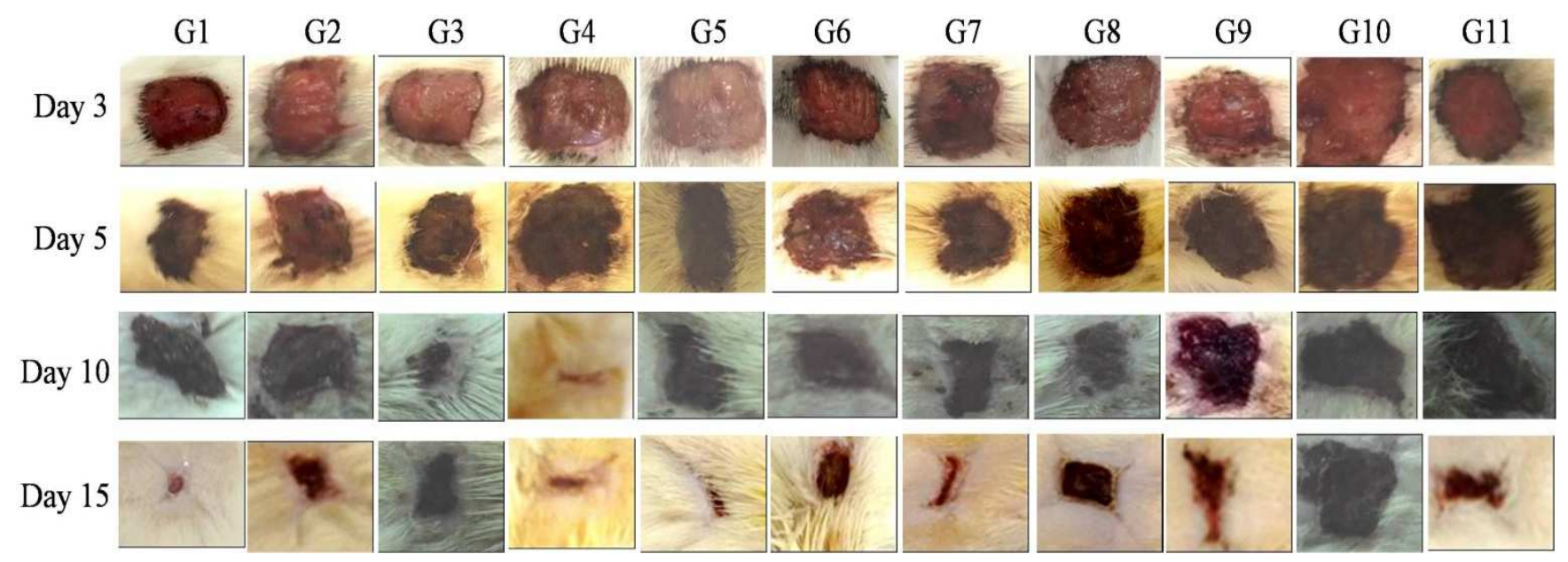

Fig. 1: Wound images of experimental rats during trial period of $15 \mathrm{~d}$

\section{Histopathology}

At the end of the trial, all the animals were sacrificed and the vital organs were carefully removed, washed with saline and observed for any treatment-related changes in gross pathology and anatomy. There were no internal pathological lesions noticed in any of the experimental animals.

The histopathology of excised wound area is summarized in table 3 . The haematoxylin and eosin stained sections of wound area were evaluated microscopically for the histopathological changes such as granulation tissue formation, epidermal closure, epithelial hyperplasia and inflammation (fig. 2). In the present study, control group (G1: nondiabetic) there was a marginal improvement in the wound healing process. Granulated tissue was moderate with partial reepithelialization. However, the epidermal closure was significant (fig. 2a). In the diabetic control group (G2) the wound healing was delayed with mild granulation and minimal epidermal closure. Partial reepithelialization and thick collagen fiber were observed (fig. $2 b$ ).

In the positive control group (G3) treated with Framycetin, the wound healing was noticeable with marked granulated tissues, restoration of adnexa and fibrosis, reepithelization and epidermal closure (fig. 2c). Group 5 and group 7 treated with a methanolic extract of aerial part of Cyclea peltata and root of Caesalpinia bonducella respectively moderate granular tissue with marked epithelial closure ensuring the efficiency in wound healing (fig. 2d, e). In other groups, there was no improvement in the wound healing parameters when compared to control.

Table 3: Histopathology observation of excision wound area

\begin{tabular}{|c|c|c|c|c|}
\hline \multirow[t]{2}{*}{ Groups } & \multicolumn{4}{|c|}{ Histopathological findings } \\
\hline & Granulation tissue & Epidermal closure & Epithelial hyperplasia & Inflammation \\
\hline G1 & $3.0 \pm 1.2$ & $3.0 \pm 0.8$ & $2.0 \pm 1.2$ & $0.5 \pm 0.7$ \\
\hline G2 & $3.5 \pm 0.6$ & $2.0 \pm 1.2$ & $2.3 \pm 1.3$ & $0.8 \pm 0.7$ \\
\hline G3 & $3.0 \pm 0.0$ & $3.3 \pm 0.5$ & $2.3 \pm 0.5$ & $0.5 \pm 0.7$ \\
\hline G4 & $3.5 \pm 0.6$ & $3.5 \pm 0.6$ & $3.3 \pm 0.5$ & $0.8 \pm 1.1$ \\
\hline G5 & $2.8 \pm 1.0$ & $3.0 \pm 0.0$ & $3.5 \pm 0.6$ & $0.9 \pm 1.2$ \\
\hline G6 & $3.0 \pm 0.0$ & $3.8 \pm 0.5$ & $2.0 \pm 0.0$ & $0.6 \pm 0.9$ \\
\hline G7 & $3.3 \pm 0.5$ & $3.5 \pm 1.0$ & $3.5 \pm 1.0$ & $1.0 \pm 1.4$ \\
\hline G8 & $6.9 \pm 0.0$ & $1.0 \pm 1.2$ & $2.0 \pm 0.0$ & $1.6 \pm 1.6$ \\
\hline G9 & $2.3 \pm 0.5$ & $2.8 \pm 1.0$ & $3.0 \pm 0.0$ & $0.9 \pm 1.2$ \\
\hline G10 & $3.0 \pm 0.0$ & $2.8 \pm 0.5$ & $2.3 \pm 0.5$ & $0.8 \pm 1.1$ \\
\hline G11 & $2.5 \pm 0.6$ & $2.0 \pm 1.2$ & $3.0 \pm 0.0$ & $0.8 \pm 0.4$ \\
\hline
\end{tabular}

Values are mean \pm standard deviation $(n=6)$ 


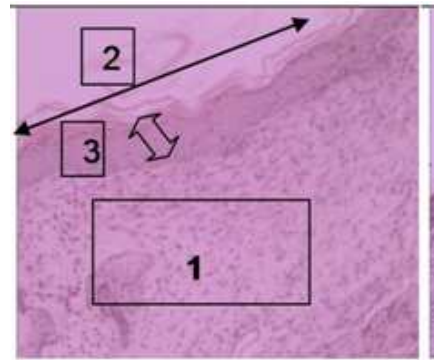

(a)

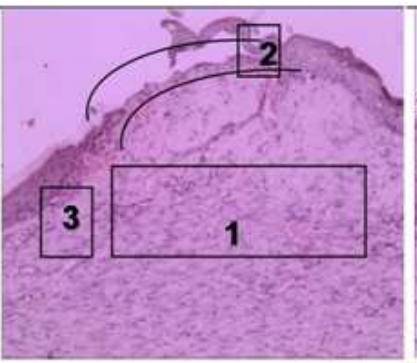

(b)

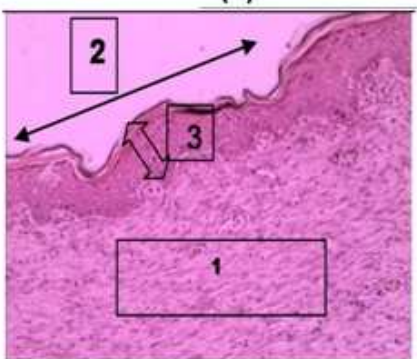

(d)

(e)

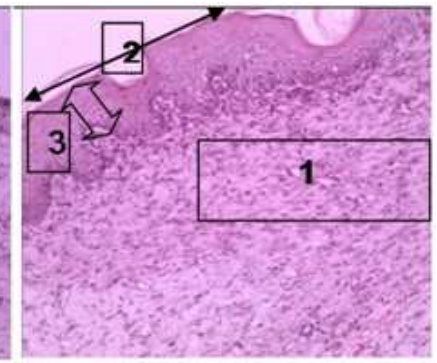

(c)

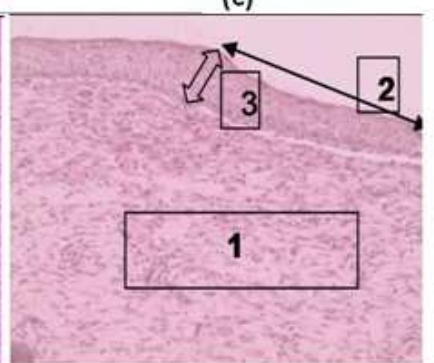

Fig. 2: Histopathological studies of the excised wound area of experimental rats. (a) Control (G1: non-diabetic); (b) Diabetic (G2: induced diabetic); (c) Positive control (G3: diabetic induced treated with Framycetin); (d) Group 5 (G5: diabetic induced treated with $100 \mathrm{mg} / \mathrm{kg}$ BW of methanolic extract of Cyclea peltata aerial part; (e) Group 7 (G7: diabetic induced treated with $100 \mathrm{mg} / \mathrm{kg}$ BW of methanolic extract of Caesalpinia bonducella root. In the figure, 1. Granulation tissue, 2. Epidermal closure, 3. Epithelial hyperplasia. Magnification 10x

\section{DISCUSSION}

Wound symbolizes a major health problem globally, especially in diabetic patients. The healing process involves epithelization, contraction, and connective tissue deposition under-regulated biosynthesis and deposition of new collagens and their subsequent maturation [44].

Earlier literature supports the effect of various solvent extracts of different plant parts on wound healing. Zaouani et al., [45] reported that methanolic extract of Centaurea africana promoted wound healing through a contraction, shorter epithelium time, higher tissue breaking strength and increased hydroxyproline. However, Suguna et al., [41] demonstrated that the alcoholic extract of Centenella asiatica improved the rate of wound healing in rats. Sunilkumar $e t$ al., [46] showed that topical administration of the aqueous extract increased cellular proliferation, promoted collagen synthesis at the wound site as evidenced by the increase in DNA, protein and collagen content of granular tissue and in tensile strength. In this regard, the present study was undertaken with various extract of test plant viz., methanolic extract of aerial part of Cyclea peltata as well as roots of Caesalpinia bonducella and ethyl acetate extract of bark and leaf of Caesalpinia bonducella to investigate their wound healing efficacy.

Fasting blood glucose values showed an average reduction in the group fed with test samples as compared to control. However as expected the glucose level was found high in diabetic-induced rats. Elevated glucose level leads to excessive neutrophil infiltration which contributes to impaired healing process [47]. Hence, blood glucose control is one of the important ways to regulate diabetic wounds [48]. Although topical treatment prevents infection, however, it may not heal the wound in diabetic patients. In the present study, although no significant $(p>0.05)$ difference was observed in blood glucose level of treated and control diabetic group, there was a tremendous reduction in the percentage of wound contraction. The data signifies the potentiality of the tested plant extract in curing wounds/cut in diabetic patients.

Wound healing activity of test sample indicated a high percentage of contraction. Wound contraction, a part of the proliferative phase of wound healing, occurs through the centripetal movement of the tissues surrounding the wound, which is mediated by myofibroblasts. Hyperglycemic status triggers the animals to become catabolic and enhance the breaking down of proteins and fat as glucose is not accessible for cell nutrition. Thus leading to actual delay in healing process [49]. Similarly, Khatri et al. [50] observed delayed wound healing in diabetic rats as compared to non-diabetic rats, however using the formulation of linezolid topical preparation an increased rate of wound contraction and hastened the epithelialization period was noticed. A study conducted by Singhal $e t$ al. [51] using an ethanolic extract of Argyreia nervosa leaves demonstrated that topical application significantly promoted wound healing as compared to the oral application.

Wound contraction, collagenation, and epithelization are crucial phases of wound healing. Hence the histopathological study of the excised wound was carried out. The phases of inflammation, macrophages, fibroblasia and collagenation are intimately interlinked. Thus, intervention at any one of these phases using drugs could eventually either promote or inhibit one or all phases of healing [52]. According to the results obtained, diabetic rats showed mild granulation and minimal epidermal closure, however, in the group treated with Framycetin, the wound healing was noticeable. Similarly, Kodati et al. [53] found a significant increase in collagen content due to enhanced migration of fibroblasts and epithelial cells in wound site during the wound healing process in the experimental rats treated with methanolic extract of Plumbago zeylanica $\mathrm{L}$. Murthy et al. [54] reported that the healing effect of 50\% methanolic extract of Bacopa monniera is through decreased myeloperoxidase and free radical generated tissue damage, promoting antioxidant status, faster collagen deposition, other connective tissue constituent formation, and antibacterial activity.

Rats treated with a methanolic extract of aerial part of Cyclea peltata and root of Caesalpinia bonducella respectively wound healing was evident. The wound contraction may be due to stimulation of interleukin-8, an inflammatory $\alpha$-chemokine which increases intracellular communication in fibroblasts and induces maturation of granulated tissue [55]. Farahpour and Habibi [56] have shown wound healing effect of Ceylon cinnamon especially with increased epithelialization in experimentally induced excision wounds in rats. Similarly, Mageswari et al. [57] studied the wound healing effect of alcohol extract of Carmona retusa root stem and leaves in the experimentally induced wound in mice. The extract specifically increased epithelization and stimulated closure of wounds. Singh $e t$ al. [58] observed $82 \%$ reduction in wound area, faster epithelization 
and a significant increase in tissue granulation on the application of a hydroalcoholic extract of $T$. chebula fruit in alloxan-induced diabetic rats excision wound, model. Singh and Sharma [58] formulated an ointment with ethanol and aqueous extract of Acacia auriculiformis and evidenced the wound healing efficiency with decreased period of epithelization, increased rate of wound contraction, tensile strength, hydroxyproline content and collagen fibre formation

\section{CONCLUSION}

In diabetic rats, methanolic extract of aerial part of Cyclea peltata and root of Caesalpinia bonducella significantly increased the wound contraction along with re-epithelization during wound healing. It improves condition at the wound site by the epithelial enclosure and moderate granulation. The results of the present study are very encouraging and the wound healing potential of the test sample in experimentally induced diabetic rats has paved the way for its application as prohealing ointment or solution in the impaired wound. Hence further study is required to unveil the mechanism through purification of chemical constituents and evaluation in clinical settings.

\section{ACKNOWLEDGEMENT}

The authors are thankful to Skanda Life Sciences Pvt. Ltd, Bengaluru, for their constant suggestions during the study

\section{AUTHORS CONTRIBUTION}

Jagadeep Chandra S: Collection of plant material, execution of experiments, animal studies

Mahadev Murthy S: Guiding and planning of experimental design

Ranjana Ramesh: Execution of experiment

\section{CONFLICT OF INTERESTS}

We declare that we have no conflict of interest

\section{REFERENCES}

1. Nagori BP, Solanki R. Role of medicinal plants in wound healing. Res J Med Plant 2011;5:392-405.

2. Pierce GF, Mustoe TA. Pharmacologic enhancement of wound healing. Annu Rev Med 1995;46:467-81.

3. Martin P. Wound healing aiming for perfect skin regeneration. Science 1997;276:75-81.

4. Sandhya S, SaiKumar P, Vinod KR, Banji D, Kumar K. Plants as potent antidiabetic and wound healing agents: a review. Hygeia J Drugs Med 2011;3:11-9.

5. Powers CA. Diabetes mellitus infections: Harrison's principles of Internal Medicine. 16th edition. McGraw Hill publishers (p) Ltd; 2004. p. 2168-9.

6. Brem H, Tomic-Canic M. Cellular and molecular basis of wound healing in diabetes. J Clin Investigation 2007;117:1219-22.

7. Grey JE, Harding KG. ABC of wound healing. Wiley Blackwell; 2006. p. 42.

8. Falanga V. The chronic wound: impaired wound healing and solutions in the context of wound bed preparation. Blood Cells Mol Diseases 2004;32:88.

9. Osariemen IJ, Olowu SS, Adevbo E, Omon EE, Victoria O, Imuetinyan EJ, et al. Aerobic bacteria associated with diabetic wounds in patients attending the clinic in a rural community in Nigeria. Global Res J Microbiol 2013;3:8-12.

10. Karodi R, Jadhav M, Rub R, Bafna A. Evaluation of the wound healing activity of a crude extract of Rubia cordifolia L. (Indian madder) in mice. Int J Appl Res Natl Prod 2009;2:12-8.

11. Mukherjee PK, Mukherjee K, Pal M, Saha BP. Wound healing potential of Nelumbo nucifera (Nymphaceae) rhizome extract. Phytomedicine 2000;7:66-73.

12. Kumar B, Vijayakumar M, Govindarajan R, Pushpangadan P. Ethnopharmacological approaches to wound healing-exploring medicinal plants of India. J Ethnopharmacol 2007;114:103-13.

13. Reddy JS, Rajeswara Rao P, Reddy MS. Wound healing effects of Heliotropium indicum, Plumbago zeylanicum and Acalypha indica in rats. J Ethnopharmacol 2002;79:249-51.

14. Pulok KM, Verpoorte R, Suresh B. Evaluation of in vivo wound healing activity of Hypericum patulum (Family: Hypericaceae) leaf extract on different wound model in rats. J Ethnopharmacol 2000;70:315-21.

15. Handa SS, Kaul MK. Supplement to cultivation and utilization of medicinal plants. RRL Jammu-Tawi; 1996. p. 727-37.

16. Kirtikar, Basu. Indian Medicinal Plants. $2^{\text {nd }}$ Editor. B.S.M.P. Singh and Periodical Experts, New Delhi; 1975;2:842.

17. Kapoor LD. Handbook of Ayurvedic Medicinal Plants. 1st Ed. CRC Press: Washington; 2005. p. 87-8.

18. The Wealth of India. Raw material, Ca-Ci, Revised Edt, Publication and Information Directorate, CS I R, New Delhi; 1992;3:6-8.

19. Shrikant I. Further flowers of Sahyadri "Field guide to additional 1200 flowers of Northwestern ghats of India. Corolla Publications-Pune, India; 2007. p. 345.

20. Deshpande DJ. A handbook of herbal remedies. Published by Agrobios (India)-Jodhpur; 2008. p. 232-3.

21. Yoganarasimhan SN. Medicinal plants of India. Vol. I. Interline publishing private limited-Banglore, Karnataka; 1996. p. 82.

22. Nadkarni AK, KM Nadkarni's. Indian Materia Medica. Popular prakashan private limited, Bombay; 2002. p. 226-9.

23. Elizabeth M, Williamson. Textbook of Major herbs of Ayurveda. Churchill (I); 2002. p. 7-11.

24. Nair CKN, Mohanan N. Medicinal plants of India (With special reference to Ayurveda). Nag Publishers, Delhi; 1998. p. 80.

25. Ambasta SPK, Kashypa, Ramchandran K, Ramesh Chand R. Ed. Useful plants of India. Publications Div, CSIR, Directorate, New Delhi, India; 1986.

26. Subramanian R, Krishnasamy G, Arunadevaraj, Sethuraman P, Jayakumararaj R. Wound healing ethnopharmacological potentials of selected medicinal plants used by malayali tribes. Int Res J Pharmacol 2011;2:132-7.

27. Vaidyaratnam PSV. Indian medicinal plants (a compendium of 500 species). Orient Longman Limited 1997;2:277.

28. Suman S, Nishteswar K. Review on Cissampelospareira and Cycleapeltata (Pathadwaya) phytopharmacological perspectives. Int J Ayurvedic Med 2013a;4:282-9.

29. Christina AJM, PackiaLakshmi M, Nagarajan M, Kurian S. Modulatory effect of Cycleapeltata Lam. on stone formation induced by ethylene glycol treatment in rats. Methods Find Exp Clin Pharmacol 2002;24:77-9.

30. Suman S, Nisteshwar K. Review of Cissampelo spareira and Cycleapeltata (Pathadwaya) ethnomedicinal perspectives. Global J Pharm Res 2013b;2:1656-62.

31. Purohit SS, Narayan DP, Arun KS, Kumar T. A Handbook of Medicinal Plants. Agrobios, India; 2003. p. 184.

32. Vijayakirubha TS, Senthamarai R, Mariya P, Praveen M. Pharmacognostical and phytochemical standards of Cycleapeltata. (Lam) Hook. f and Thomson leaves. J Chem Pharm Res 2012;4:1465-9.

33. Vaidyaratnam PSV. Indian medicinal plants (a compendium of 500 species). Published by Orient Longman Limited; 1997. p. 277.

34. Oommen S, Ved DK, Krishnan R. Tropical Indian medicinal plants propagation methods. Published by Foundation for the revitalisation of local health traditions, Banglore; 2000. p. 125-6.

35. Raj DAR, Jeeva S, Prakash JW, Antonisamy JM, Irudayaraj V. Antibacterial activity of selected ethnomedicinal plants from South India. Asian Pacific J Trop Med 2011;4:375-8.

36. Kingston C, Nisha BS, Kiruba S, Jeeva S. Ethnomedicinal plants used by the indigenous community in the traditional healthcare system. Ethnobot Leaflets 2007;11:32-7.

37. Bhandary MJ, Chandrashekar KR, Kaveriappa KM. Medical ethnobotany of the Siddis of Uttara Kannada district, Karnataka, India. J Ethnopharmacol 1995;47:149-58.

38. Bhandary MJ, Chandrashekar KR. Herbal therapy for herpes in the ethnomedicine of coastal Karnataka. Indian J Traditional Knowledge 2011;10:528-32.

39. Santhkumari P, Prakasam A, Pugalendi KV. Modulation of oxidative stress parameters by treatment with Piper beetle leaf in streptozotocin-induced diabetic rats. Int J Pharmacol 2003;35:373-8.

40. Kapoor R, Kakkar P. Naringenin accords hepatoprotection from streptozotocin-induced diabetes in vivo by modulating mitochondrial dysfunction and apoptotic signalling cascade. Toxicol Reports 2014;1:569-81. 
41. Suguna L, Shivakumar P, Chandrakasan G. Effect of Centella asiatica extract on dermal wound healing in rats. Indian J Exp Biol 1996;34:1208-11.

42. Jagdish VK, Rana AC, Anirban RC. Prohealing effects of Cinnamomum zeylanicum bark. Phytother Res 2003;17:970-2.

43. Boehmerle W, Huehnchen P, Peruzzaro S, Balkaya M, Endres M. Electrophysiological, behavioural and histological characterization of paclitaxel, cisplatin, vincristine and bortezomib-induced neuropathy in C57Bl/6 mice. Sci Rep 2014;4. Doi:10.1038/srep06370

44. Agarwal PKA, Singh K, Gaurav S, Goel H, Khanna D, Goel RK. Evaluation of wound healing activity of extracts of Plantain banana (Musa sapientum var. Paradisiaca) in rats. Indian J Exp Biol 2009;47:32-40.

45. Zaouani M, Bitam A, Baz A, Nenali Y, Ben-Mahdi MH. In vivo evaluation of wound healing and anti-inflammatory activity of methanolic extract of roots of Centaurea africana (L.) in a topical formulation. Asian J Pharm Clin Res 2017;10:341-6.

46. Sunilkumar, Parameshwaraiah S, Shivakumar HG. Evaluation of topical formulations of aqueous extract of Centella asiatica on open wounds in rats. Indian J Exp Biol 1998;36:569-72.

47. Lan CCE, Wu CS, Huang SM, Wu IH, Chen GS. High glucose environment enhanced oxidative stress and increased interleukin8 secretion from keratinocytes. Diabetes 2013;62:2530-8.

48. Yazdanpanah L, Nasiri M, Adarvishi S. Literature review on the management of diabetic foot ulcer. World J Diabetes 2015;6:37-53.

49. Gautam MK, Goel RK. Wound healing effect of Ocimum sanctum leaves extract in diabetic rats. World Academ Sci Eng Technol 2013;81:144-7.

50. Khatri SK, Rathman and M, Nikhila R. Formulation and evaluation of wound healing activity of linezolid topical preparation on diabetic rats. Int J Appl Pharm 2016;8:30-6.

51. Singhal AK, Gupta H, Bhati VS. Wound healing activity of Argyreia nervosa leaves extract. Int J Appl Basic Med Res 2011;1:36-9.
52. Vinothapooshan G, Sundar K. Wound healing effect of various extracts of Adhatoda vasica. Int J Pharma Biol Sci 2010; 1:530-6.

53. Kodati DR, Goud KP, Burra A, Galipelly SK. Evaluation of wound healing activity of methanolic root extract of Plumbago zeylanica L. in wistar albino rats. Pelagia Res Library Pharm Sinica 2011;2:239-48.

54. Murthy S, Gautam MK, Goel S, Purohit V, Sharma H, Goel RK. Evaluation of in vivo wound healing activity of Bacopa monniera on different wound model in rats. Biomed Res Int 2013;1-9. http://dx.doi.org/10.1155/2013/972028

55. Moyer KE, Saggers GC, Allison GM, Mackay DR, Ehrlich HP. Effects of interleukin-8 on granulation tissue maturation. J Cell Physiol 2002;193:173-9.

56. Farahpour MR, Habibi M. Evaluation of the wound healing activity of an ethanolic extract of Ceylon cinnamomum in mice. J Vet Med 2012;57:53-7.

57. Mageswari S, Karpagam S, Aadinaath Reddy G. Evaluation of wound healing activity of the plant Carmona retusa (vahl) masam, in mice. Int J Integr Sci Innovation Technol 2015;4:1-4.

58. Singh R, Koppikar SJ, Paul P, Gilda S, Paradkar AR, KaulGhanekar R. Comparative analysis of the cytotoxic effect of aqueous cinnamon extract from Cinnamomum zeylanicum bark with commercial cinnamaldehyde on various cell lines. Pharm Biol 2009; 47:1174-6.

59. Singh S, Sharma N. Evaluation of wound healing activity of Acacia auriculiformis A. Cunn. Stem bark. Asian J Pharm Clin Res 2014;17:204-7.

\section{How to cite this article}

- Jagadeep Chandra S, Mahadev Amurthy S, Ranjana Ramesh Evaluation of the wound healing activity of Caesalpinia bonducella and cyclea peltata extracts in experimentally induced diabetic rats. Int J Pharm Pharm Sci 2017;9(10):211-217. 